sided in the unavoidable absence of the president, Mr. Augustus John, and at which fifty-five members and guests were present. The Gypsy Lore Society was founded in 1888 by Charles Godfey Leland ("Hans Breitmann") and David MacRitchie of Edinburgh. Leland's enthusiasm for gypsy studies, characteristically overpowering, dated from 1870 , when he settled in England for a period of years. Although he wrote several books on the gypsies between 1873 and 1882 , it was not until 1888, three years after his return to England, that his desire to promote a wider interest in the investigation of the gypsy problem took practical shape in the foundation of a society devoted to that object; and indeed its formation was owing largely to his association with the organizing ability and scholarly habit of mind of MacRitchie, to whom also was due, with John Sampson and R. A. S. Macfie, the resuscitation of the Society in 1907, when it had been dormant for a period of years through lack of funds. Among the eleven original members, who formed the nucleus of the Society, were H. T. Crofton, Elizabeth Robbins Pennell, Leland's niece, famous as an interpreter of Ibsen's heroines on the stage, the Archduke Joseph of Austria, a fluent Romani linguist, Sir Richard Burton, the famous, if difficult, orientalist and traveller, Paul Bataillard, F. H. Groome, most eminent of the early students of gypsy folk-lore, and Walter Herries Pollock; while one of the earliest adherents in the United States was Mary Alicia Owen, later known as an authority on the folk-lore of the American Indian, whose early studies of the traditional tales and beliefs of the negroes of Missouri, if modelled on the "Uncle Remus" of Georgia of Joel Chandler Harris, were directly inspired by Leland's encouragement.

IN an introductory article which opens a special jubilee number of the Journal of the Gypsy Lore Society, the editor, Archdeacon F. G. Ackerley, enumerates some of the more noteworthy contributions to the investigation of the gypsy problem which have appeared in its pages and elsewhere since the foundation of the Society. Among contributors to the Journal, the late Dr. John Sampson naturally takes a high place, not only on account of his linguistic studies, but also for his collection of Welsh Romani folk-tales; but it will be generally agreed that the term 'epoch-marking' here applied to Prof. R. A. S. Macalister's collection of material bearing on the language of the Nawar of Palestine is appropriate in more than a conventional and complimentary sense. It gave a new orientation to the study of the gypsy problem. Outside its own publications, the influence of the Society is to be seen in Dr. John Sampson's "Dialect of the Gypsies of Wales" (1926), which has been termed "the best of all Gypsy linguistic studies in any language" and Prof. E. Pittard's "Les Tsiganes ou Bohémiens" (1932) in which "is presented once and for all the physical anthropology of the race". Two great services the Society has performed for gypsy studies: it has abolished the pseudo-romantic rubbish which formerly passed for gypsy-lore, and it has exploded the popular association of gypsies with Egypt by laying down the true lines for the investigation of the problem of their origin. It is difficult to say which has been the greater service to learning.

\section{Archæological Collections in Spain}

NotwithstANDING reports of damage sustained by archæological collections in the museums of Madrid, it is now announced that an official verification by the Ministry of Public Instruction and the Municipality of Madrid has established the fact that the collections of both the Archæological Museum and the Anthropological Museum of Madrid are intact. Prof. Bosch Gimpera, to whom the editors of $L$ 'Anthropologie $(48,3-4 ; 1938)$ are indebted for the information, goes on to add that the other museums of the area under the Republican Government have been preserved from damage, while the official departments responsible for antiquities are taking every necessary precaution for their safety. As regards the museum at Valencia and the Catalan museums, Prof. Bosch Gimpera, as head of the antiquities service, is able to give his own personal assurance of their safety to his archæological colleagues outside Spain.

\section{Italian Anthropological Expedition to Erythraea}

ON his return at the close of last year from an expedition to the Tana basin of Ethiopia, Prof. I. Cipriani, director of the Anthropological I Laboratory of the University of Florence, was forthwith placed in charge of an anthropological mission to northern Erythraea for the purpose of studying the littleknown peoples north of Cheren. This mission was under the joint auspices of the Royal Academy of Italy and the Bureau of Colonial Studies of Florence. The expedition lasted from December 1937 until March 1938. According to a preliminary note of the results (L'Anthropologie, 48, 3-4; 1938), anthropometric measurements were made of 450 subjects, of whom there were 70 Bogo, 94 Mària, 26 Habab, and 159 representatives of groups adjacent to the last-named. For purposes of comparison, measurements were also made of 29 Abyssinians, as well as 30 Baria women and 20 Rasciàida. The blood groups were tested in 110 subjects. A further result of the expedition was the discovery of a large number of rock paintings in the granite caves of Carora near the Anglo-Egyptian frontier, as well as of stone implements of palæolithic type, the first to be recorded in Erythraea. Finally the expedition brought back to Italy 68 masks taken from the living, and more than two thousand photographs of ethnographical and anthropological subjects.

\section{Stone Age Village in Yorkshire}

Now that archæological research aims at the reconstruction of a cultural phase as a whole, rather than at bringing to light by excavation individual antiquities of exceptional interest or artistic merit, the announcement of the discovery of a remote but complete village of the stone age at Rinyo on the Island of Rousay, Orkney (The Times, July 29) has an importance which transcends the intrinsic interest of any individual object likely to be obtained there. 
In the present instance, there is added its bearing on the site of Skara Brae, the similar village discovered and excavated some ten years ago, of which the significance for our knowledge of stone age culture and more of life was such that Prof. V. Gordon Childe at the time described it as a veritable Knossos of the north. The new site defines more nearly the dating of the culture, left somewhat indeterminate, at Skara Brae. The discovery of a portion of a beaker, in association with objects of the Skara Brae type, fixes the period of occupation at somewhere about the transition from stone to bronze in Great Britain, that is at about 1500 B.c. Further the Rinyo village, being apparently complete, should supply details which at Skara Brae had been swept away by the encroachments of the sea on the sand dunes. The Rinyo settlement has been excavated by Mr. Walter W. Grant, with whom has been associated Prof. Gordon Childe. Below the floor in which the beaker fragment was discovered, traces of earlier occupation have been found. These are in the form of commodious stone houses, provided with recesses for beds, built dressers and even a system of drainage. In addition to open hearths, some of the houses have clay ovens, a novel feature. It is anticipated that eventually excavation will give a complete picture of a whole stone age settlement, unique in Britain, and indeed in western Europe, and at the same time throw a new light on the social organization and economy of a neolithic community.

\section{Rhodesian National Museum}

IN reference to the announcement of the proposed National Museum for Southern Rhodesia in the neighbourhood of the Zimbabwe ruins (see NATURE, July 9, p. 65), Mr. F. M. Collins writes to suggest the possibility of a confusion between the Victoria Falls and Fort Victoria, the township one hundred and eighty miles east of Buluwayo, near which the ruins are situated, while their distance from the Falls is by air approximately four hundred miles. 'Proximity', however, the term in the comment in these columns to which $\mathrm{Mr}$. Collins takes exception, is, as he admits, relative, and as the general sense indicated was used in comparison with, for example, the distance from Cape Town, which would affect students and tourists, rather than in relation to absolute mileage.

\section{Science and the Way to Peace}

AN "Appeal to the Scientists of the World" has reached us from India. The author, Dr. Bhagavan Das of Benares, a member of the Legislative Assembly of India, refers to the imminent peril of another world war, far surpassing the last in horror and destructiveness, and the frightful strain meanwhile imposed on mankind by preparation for defence. $\mathrm{He}$ seeks to show that a heavy responsibility for this state of affairs rests on the learned world as a whole, partly because modern warfare owes its peculiarly devastating character to scientific research and the collaboration of men of science with the organizers of war and partly because the ideas that motivate wars are products of the speculations of philosophers and the vulgarization and misapplication of theories invented by men of science, notably that of the ascent of man through the struggle for existence and survival of the fittest. He quotes from the records of ancient Aryan wisdom: "Science (Vidya) came to the man of wisdom, the man of knowledge and purity, and said to him : guard me as a sacred trust ; give me not to the wicked and sinful, but only to the pure of heart and large of mind; so only will I be strong to nourish mankind; otherwise I will only destroy thee and thy pupils and thy people." So in our own day Alexis Carrel in "Man the Unknown" writes: "The environment which science and technology have succeeded in developing for man does not suit him because it has been constructed at random without regard for his true self." Therefore, the appeal says, it is "up to" the learned world to get together and do something about it. Peradventure where politicians have failed men of science may find a way of approach to disarmament, military and economic.

\section{The Ontario Research Foundation}

THE report of the Ontario Research Foundation for 1937 (Sessional Paper, No. 52. Pp. 35. Toronto : King's Printer) refers to an increase in the amount of research work carried out in contact and in co-operation with industrial companies, the revenue received for services rendered to industry itself having increased by thirty per cent. The Textiles Department has during the year developed a launderometer for determining the fastness of dyed goods to washing, a fadeometer for determining the fastness of coloured fabrics to light, a crock-meter for determining fastness of dyes to rubbing, and an autographic tensile strength and elongation tester for determining the strength, extensibility and yarn slippage of materials. The Engineering and Metallurgy Department continued its investigation on summer comfort standards for the Toronto district and also its study of the resistance to abrasion of iron and steel balls under the conditions existing in the grinding mills of mines. In the Department of Chemistry, the development of a laboratory for the study of problems relating to paper, printing and adhesives has been completed. Work on the transfer of pigments from aqueous pastes to an oily medium by methods which are commercially feasible lıas reached its final stages and in addition to the mechanical problem an emulsifying agent is required which is not detrimental to the final product. The equipment and organization of a laboratory for the study of plastics has been commenced, and a new laboratory has also been inaugurated to study problems associated with the manufacture of waxed paper and similar products. The Department of Biochemistry has continued its investigations on a combined system of tannage for sole and belting leather and on problems connected with the Matzka process for the preparation of fruit juices which are stable for prolonged periods and retain their original flavour and content of vitamins. Investigations carried out by the Department of Agriculture have 